\title{
Characteristics Investigations of Dry Bamboo Ash Fractional Replaced Cement with in M25 Grade Concrete
}

\author{
Vijayvenkatesh Chandrasekaran \\ Structural Engineering, School of Civil Engineering, Sastra Deemed to be University, Thanjavur 613401, India \\ Corresponding Author Email: ramathutham@gmail.com
}

https://doi.org/10.18280/acsm.450207

Received: 24 March 2020

Accepted: 10 August 2020

\section{Keywords:}

dry bamboos ash, 53 grade of cement, $M$ sands (fine aggregate), coarse aggregate

\begin{abstract}
Most bamboos are used in-house ceiling, Ornament works behavior science of earliest culture regulations. If fresh and dry stages bamboos are equally important, of construction works. Green stage bamboos working process of interlocking formations woodworks and dry stage bamboos are working in support for centering for slabs, tunneling or varies constructional purposes. These papers say about dry bamboos ash to use the sub stained to mixed the partially replaced within 53 grades of cement. In 20, 30 , and $40 \%$. And constituent of mixing ratio is M25 grade of concrete $(1: 1: 2)$. And its process of proper casting of cubes, beams and cylinders to put in to the test analysis for strength, absorption tastings machines and these each types of test result are higher values. Because its better constituent DBA ash mixed with cement substance identical strength attained the concrete cubes, cylinders and beams. And its improved concrete strength and highly interlocking ability of friction bonding into the coarse and fine aggregate of the concrete. And same time its high workability.
\end{abstract}

\section{INTRODUCTION}

The mixing dry bamboo ash material made from the dry environmental waste properties, followed by a functional process to manufacture in an intimate mixture of cement, sand grain particles mixed with proportionate [1]. It reacted a binding element of lime, cement, and water. The properties and characteristics of the mortars mainly depend on the nature of the binder component [2]. Even though mortar makes positive brick masonry structures and masonry wall, it the stage a critical function in the better performance of the load bearing structure [3]. It does not only bond with the individual units together the binding properties, but it also protects seals with the strategies environmental protected the building against moisture, air and water penetrations [4]. The compressive strength of concrete cubes, beams and cylinders are it attained the required strength [5]. Compressive strength of concrete increases. With an increase in cement content viseversily with an increase in sand, coarse aggregate water or air content. Flexural strength is also important because it measures the ability of a concrete to resist the cracking [6]. Within arrange to adjust to improve the properties of the concrete, dissimilar harvest or additional constituents are mixed with the basic components of cement and fine aggregates [7]. At the earlier time, commonly used products were composed of natural substances such as blood (decomposed) bonding natures for (e.g.: china wall) egg yolk, animal glue. But today, admixtures generally of industrial or agricultural byproducts, reminiscent of (fly ash or blast furnace slag, silica fume, metakaolin, rice husk ash, and periwinkle shell ash, bamboo ash, egg shell ash) are individual used in mortar and concrete [8]. It is also established that dry bamboo stem Ash (DBS), which is obtained from the burning of dried bamboo stem, has the latency of a pozzolan for use as a cement partial substitution in concrete [9]. A revise on the pozzolanic action of DBS by firing the stem in an unwrap atmosphere and after firing at for few hours. And after the open furnace and collected the sample amount of bamboo ash [10]. The efficiency of the ash with calcium hydroxide, magnesium chloride showed that the ash is pozzolanic in nature [11]. It is in the accumulation report that the binding reactively augmented with instance and temperature [12]. When 20,30, 40\% (DBS) was mixed in 53 grades of cement, the compressive strength at 7,14,28 days complete hydrations of samples [13]. Before testings, the individuality of DBS coefficient of cohesive soil and added to cohesive soil in addition to as a balancing to lime in the stabilization of cohesive soil [14]. If highway construction, railway constructions replacements of sub grades in loose soils [15]. It was reported that DBS has the potential for stabilizing lateritic soils as well as increasing the strength of lime stabilized lateritic soil for railways and highway construction [16]. Iorliam et al examined the effect of DBA on cement stabilization of for use as flexible pavement construction material and found that the use of examples $20 \%$ replacement of cement $=80 \%$ of cement $+20 \%$ of DBA suitable for use as sub-base materials in concrete mixings. The use of only BLA as stabilizing agent was carried out by Amu and Babajide, they identifications the BLA bamboos leaf ash and experimental that the strength properties of equality to DBS treated methods for experimental analyzing. Minimum values of budgets estimations for material costs and economical, saving better strength. It specified for road building materials. The mechanical properties for mix proportioned the Dry Bamboo ash in M25 grade of concrete better bindings and weight less concrete and compared to nominal M25 concrete Standard sizes of concrete cubes, And quick setting times initial setting 
time- 10minutes and after final settings- 25minutes [17]. And strength, workability, and durability performance, is the option same in normal M25 grade of concrete [18]. Therefore, this study of investigating the physical and mechanical properties of concrete made from ordinary Portland cement raw with DBS by an outlook to the efficiency of the appropriateness DBS cement M25 concrete construction works.

\section{EXPERIMENTAL MATERIALS}

\subsection{Cement}

The cement used to be ordinary Portland cement 53 (OPC 53). All properties of cement were determined by referring IS 12269 - 1987. The specific gravity of cement is 3.15 . The initial and final setting times were found as 55 minutes and 258 minutes respectively. The standard consistency of cement was $30 \%$.

\subsection{Fine aggregates}

M-sand was used as a fine aggregate [19]. The specific gravity and fineness modulus were 2.56 and 2.92 respectively. A compact aid of heavy blowing sands is 1595 .

\subsection{Coarse aggregates}

The $20 \mathrm{~mm}$ size aggregates-The coarse aggregates with a size of $20 \mathrm{~mm}$ were tested and the specific gravity value of 2.78 and fineness modulus of 7.56 find and selected. The coarse aggregate fine angular sharpened edges aggregates were available from local sources. The compact aid of heavy blowing sands is 1700 .

\subsection{Water}

Potable water used for mixing and curing purposes. Preparing of concrete and for this purpose used in the Water cement ratio is $\mathrm{W} / \mathrm{C}$ of $0.52(52 \%)$ water range 6 to $7.5 \mathrm{ppm}$.

\subsection{Dry bamboo ash}

The bamboo stems are collected to near the wood store markets. The stems were taken to the department labs. The collective DBA samples and put into a gas furnace and fireinduced to the temperature eight thousand degree Celsius. And after taking the stand slags dry bamboo ash into the furnace. The DBA obtained the calcium hydroxide and magnesium hydroxides. The specific gravity of DBA dust is found to be 2.64 and the fineness is found to be $7.2 \%$. The results of bulk density and specific gravity test on dry bamboo ash are shown in Table 1.

Table 1. Test results of dry bamboo ash

\begin{tabular}{cccc}
\hline S. No & Parameter & $\begin{array}{c}\text { Test } \\
\text { result }\end{array}$ & Specification \\
\hline 1. & Bulk density $\left(\mathrm{kg} / \mathrm{m}^{3}\right)$ & 1013 & 1127 \\
2. & Specific gravity & 3.2 & $3-4$ \\
\hline
\end{tabular}

As shown in Figure 1, represents the DBA stem after burning process in a furnace. The sizes of the each peaces carbon to poured the water and collected the carbon DBA in sags.

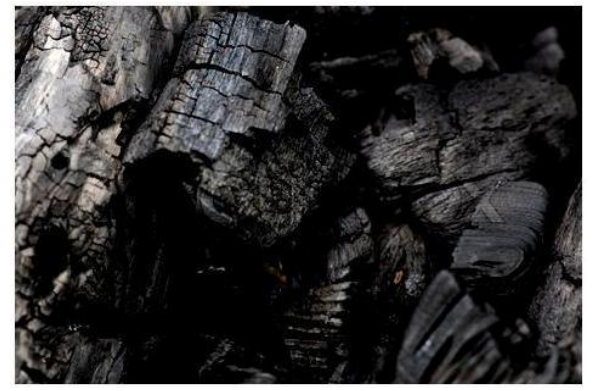

Figure 1. DBA stem after burning process

As shown in Figure 2, represents the solid carbon DBA after burned. To put into the grinding process. If fine-grained and the test passed to mixed to combinations of cement M25 grade concrete.

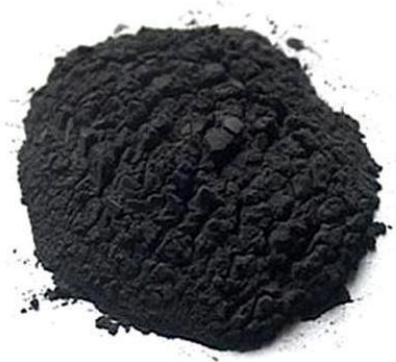

Figure 2. The solid carbon Dry bamboo ash (DBA) after burned

\section{METHODOLOGY}

The evaluation of tile powder which is used as a replacement of cement material begins with the concrete testing. With the conventional concrete $20 \%, 30 \%, 40 \%$ of the Dry Bamboo ash powder replaced with cement. Weight batching is done by volume, but most specifications required that batching be done by mass rather than volume. Cement: 53 grade $(\mathrm{OPC})$, Content $=330 \mathrm{~kg} / \mathrm{m}^{3}$. Combination material mix proportion: (M25 grade) 1:1:2 is 10262-2009. Batching of mixing material is Weight batching is done by the perfectly partial or sustainable replacement of cement [20] concrete mixings. The percentage replacements of Ordinary Portland cement (OPC) by Dry Bamboo ash powder were, $20 \%, 30 \%$ and $40 \%$. The concrete mix design used in this investigate exertion was made using Binders for cement + DBA powder, Sand and Gravel. The concrete mix proportion was $1: 1: 2$ by weights of weight batching. Test specimens consisting of $150 \times 150 \times 150 \mathrm{~mm}$ cubes for Compressive strength, $150 \mathrm{~mm} \Phi, 300 \mathrm{~mm}$ Length cylinders for split tensile strength and $150 \times 150 \times 700 \mathrm{~mm}$ beam for flexural strength using different percentage glass [21] fiber for an M20 grade of concrete mix were cast and tested as per IS: 516 and 1199. A tamping rod can be used to force, especially cohesive concretes through the hoppers 25 times continue blows and removed air and water voids. This mass is compared to the mass of fully compacted concrete in the same cylinder achieved with hand Roding or vibration. The compaction factor is defined as the ratio of the mass of the concrete compacted in the compaction factor apparatus to the mass of the fully compacted concrete. The standard test apparatus, described above, is appropriate for maximum aggregate sizes 
of up to $20 \mathrm{~mm}$. A larger apparatus is available for concretes with maximum aggregate sizes of up to $40 \mathrm{~mm}$. The compaction factor test output is more in sequence, compatibility than the slump test. The test is a dynamic test and thus is more appropriate than static tests for highly concrete mixtures.

\section{THEORY OF FAILURES}

\subsection{Maximum principal stress theory}

Design criteria for Maximum principal stress, Maximum principal stress $(\sigma)$ must not exceed the working stress. Fragile material which doesn't failure yielding load, but failure brittle fracture.

$$
\sigma_{1} \leq \mathrm{f}
$$

\subsection{Maximum principal strain theory}

Minimize principal strain $=$ yield point of the strain in simple compression.

$$
\sigma_{1}-1 / \mathrm{m}\left(\sigma_{2}+\sigma_{3}\right)=\mathrm{f}_{\mathrm{y}}(\mathrm{comp})
$$

Maximum shear stress $\left(\sigma_{1}\right)$ in simple tension $=1 / 2$ to tensile stress $\left(\sigma_{3}\right)$.

$$
\sigma_{1}-\sigma_{3}=f_{y}
$$

\subsection{Maximum strain energy theory}

When energy per unit volume absorbed at the point is equal to energy absorbed per unit volume. Subjected to the elastic limit under a uniaxial state of stress $(\sigma 1)$ as occurs in simple tensile stress $\left(\sigma_{2}\right)$.

$$
\sigma_{1}^{2}-\sigma_{2}^{2}-2 / m \sigma_{1}-\sigma_{2}=f_{y}^{2}
$$

\subsection{Maximum shear strain energy theory}

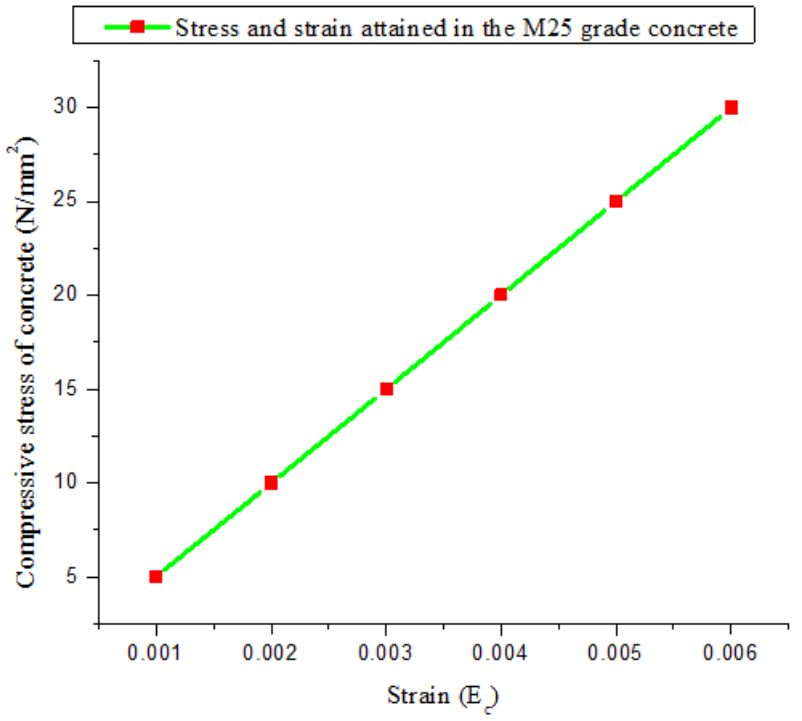

Figure 3. Design stress of concrete
If any portions of strain energy producing energy change in dimensions of material assumed completely responsible for the failure of material by yielding. These theories analyzed the good experimental results as shown in Figure 3, where are various combinations of principal stress for the material.

$$
\sigma_{1}^{2}+\sigma_{2}^{2}-\sigma_{1} \sigma_{2}=f_{y}
$$

\section{RESULT AND DISCUSSION}

\subsection{Compressive strength tests on concrete cubes}

The results of the compressive strength tests on concrete cubes are shown in Table 2.

As shown in Figure 4, represented the values of strength in 7 -days compared to 28-Days of strengths. It most preferable for 28-day's strength relevant to another or normal mix concretes represented the compressive strength of cube samples 28-days curing cubes results in high strength and load withstanding capacity of cube blocks. Dimensions of testing concrete cube: $150 \mathrm{~mm} * 150 \mathrm{~mm} * 150 \mathrm{~mm}$. The procedure the test specimen is take away from the specimen beginning of water after particular curing duration (7, 14, 28 days) time and clean away glut water from the surface is cube placed in a UTM universal testing machine. The cubes perfect required rule of dimensions without any break volumetric perfect cast. Put the specimen samples in the UTM machine in such a way that the load applied to the conflicting sides of the concrete cube casts as shown in Figure 5, Where submit the concern the load gradually applied with no shock and incessantly at the tempo.

Table 2. Compressive strength of concrete cubes with various percentages of DBA powder

\begin{tabular}{cccc}
\hline $\begin{array}{c}\text { DBA } \\
\text { powder \% of } \\
\text { replacement }\end{array}$ & $\begin{array}{c}\text { 7-Days } \\
\left(\mathbf{N} / \mathbf{m m}^{\mathbf{2}}\right)\end{array}$ & $\begin{array}{c}\text { 14-Days } \\
\left(\mathbf{N} / \mathbf{m m}^{\mathbf{2}}\right)\end{array}$ & $\begin{array}{c}\mathbf{2 8 - D a y s} \\
\left(\mathbf{N} / \mathbf{m m}^{\mathbf{2}}\right)\end{array}$ \\
\hline $20 \%$ & 21.54 & 27.56 & 37 \\
$30 \%$ & 20.25 & 26.30 & 34.50 \\
$40 \%$ & 20.10 & 25 & 32 \\
\hline
\end{tabular}

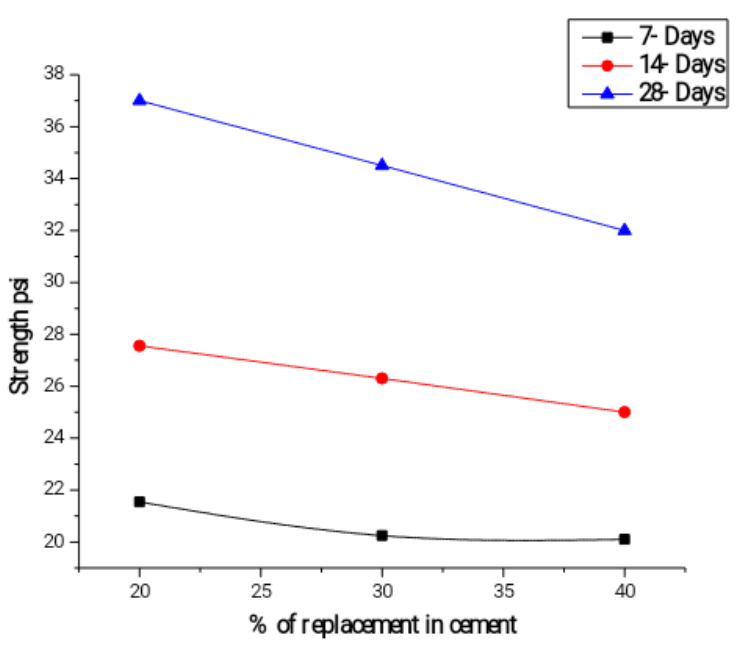

Figure 4. Compressive strength of concrete Cube 


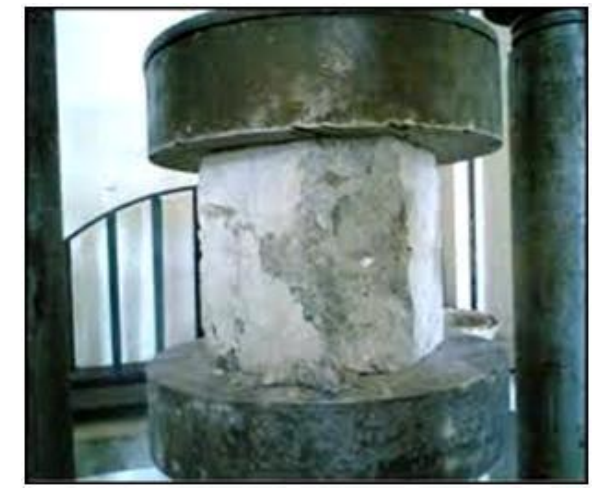

Figure 5. Experimentations for UTM Cube compressions test

$$
\sigma=\mathrm{P} / \mathrm{A}
$$

$\mathrm{P}=$ Maximum compressive load

$\mathrm{A}=$ Cross sectional area

\subsection{Split tensile strength test on concrete cylinder}

The result of the split tensile strength of concrete cylinder is shown in Table 3.

As shown Figure 6, represented the values of strength in 7days compared to 28-Days of strengths in concrete cylinders. It most values analyzed for 28-day's strengths for after curing. It compared to the relevant of another or normal mix of conventional concretes represent a compressive strength of cylinders samples. 28-days curing at cylinders results in high strength and load withstanding capacity of concrete cylinders sample. Dimensions of cylinders: $150 \mathrm{~mm}$ diameter and $300 \mathrm{~mm}$ longs. The procedure took the damp specimen of water following 7, 14, 28 days of hydration process. Clean out wet from the outside of the concrete cylinder specimen. Fix the diameter lines on the concrete cylinder two ends of the specimen to make certain that they are in the similar axial place. And after placing the put the as shown in Figure 7, UTM for the necessary range. The largest sections of cylinders equivalent to the depth of subjects uniformly continue load stress acting in horizontally. The stress acting at the about $1 / 6$ the depth and enduring 5/6 the depth study on tension due to Poisson's effects.

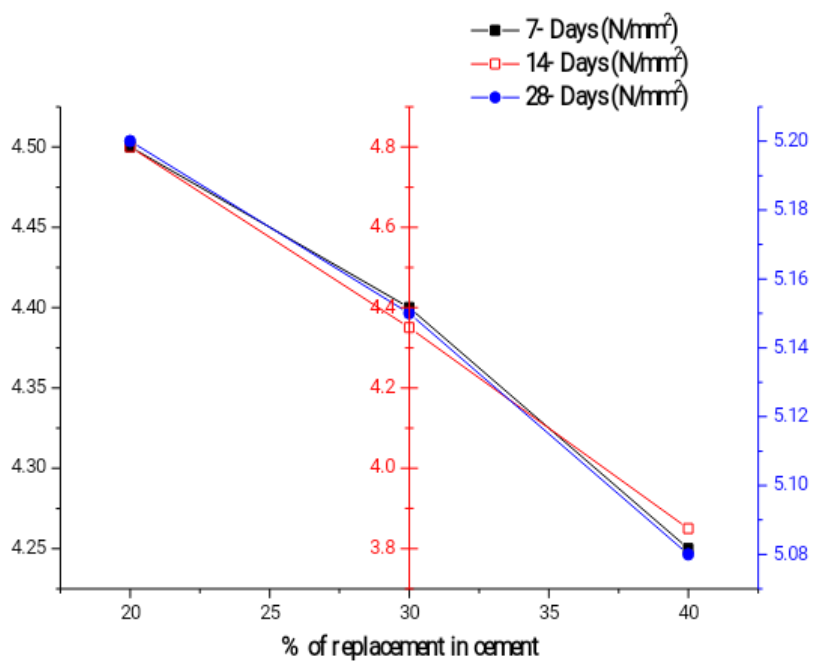

Figure 6. Split tensile strength of concrete cylinders
Table 3. The result of the split tensile strength on concrete cylinder

\begin{tabular}{cccc}
\hline $\begin{array}{c}\text { Dry Bamboo } \\
\text { ash (DBA) } \\
\text { powder \% of } \\
\text { Replacement }\end{array}$ & $\begin{array}{c}\text { 7-Days } \\
\left(\mathbf{N} / \mathbf{m m}^{2}\right)\end{array}$ & $\begin{array}{c}\text { 14-Days } \\
\left(\mathbf{N} / \mathbf{m m}^{\mathbf{2}}\right)\end{array}$ & $\begin{array}{c}\mathbf{2 8 - D a y s} \\
\left(\mathbf{N} / \mathbf{m m}^{\mathbf{2}}\right)\end{array}$ \\
\hline $20 \%$ & 4.50 & 4.80 & 5.20 \\
$30 \%$ & 4.40 & 4.35 & 5.15 \\
$40 \%$ & 4.25 & 3.85 & 5.08 \\
\hline
\end{tabular}

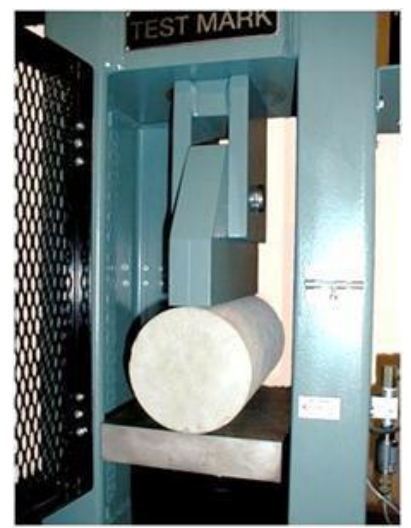

Figure 7. Experimentations for UTM lower pattern sets CM2500 series machines

$$
\mathrm{Ft}=2 \mathrm{P} / \pi \mathrm{DL}
$$

$\mathrm{P}=$ Compressive load at failure

$\mathrm{L}=$ Cylinder length

$\mathrm{D}=$ Diameter of cylinder

\subsection{Flexural strength test of concrete beam}

The result of the Flextural strength of concrete beam is shown in Table 4.

As shown in Figure 8, represented the values of strength in 7-days compared to 28-Days of strengths in concrete beams. It most values analyzed for 28-day's strengths for after curing. It compared to the relevant of another or normal mix of conventional concretes represented the compressive strength of the beam. It refers the IS (STD): 516-1959 technique of test in a concrete beam. Dimensions of Beams: $150 \mathrm{~mm} * 150 \mathrm{~mm} * 700 \mathrm{~mm}$. The procedures of arrangements shown in Figure 9, the testing samples models in three-layer forms in identical thickness tamped each layer in 35 blows in tamping rods. And take after curing the beam cleaning the outer surface of the beam, raw strip papers used it to clean the manner surface of the beam and supporting UTM roller. The test specimen placed on the hydraulic UTM and its fixed on the role in the horizontal direction of the beam. They should be applied on gradually to beam surface. $(400 \mathrm{Kg} / \mathrm{min}$ $=150 \mathrm{~mm}$ specimens).

Table 4. The result of the Flextural strength of concrete beam

\begin{tabular}{cccc}
\hline $\begin{array}{c}\text { Dry Bamboo } \\
\text { ash powder } \\
\text { (DBA) \% of }\end{array}$ & $\begin{array}{c}\text { 7-Days } \\
\left(\mathbf{N} / \mathbf{m m}^{\mathbf{2}}\right)\end{array}$ & $\begin{array}{c}\text { 14-Days } \\
\left(\mathbf{N} / \mathbf{m m}^{\mathbf{2}}\right)\end{array}$ & $\begin{array}{c}\mathbf{2 8 - D a y s} \\
\left(\mathbf{N} / \mathbf{m m}^{\mathbf{2}}\right)\end{array}$ \\
\hline Replacement & & & \\
\hline $20 \%$ & 4.3 & 4.76 & 5.12 \\
$30 \%$ & 4.7 & 4.81 & 5.06 \\
$40 \%$ & 5.2 & 6.8 & 7.58 \\
\hline
\end{tabular}




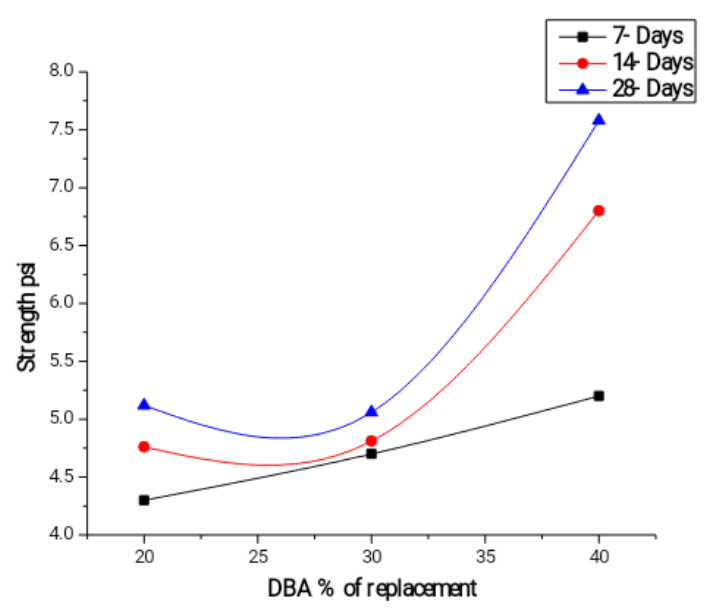

Figure 8. Flextural strength of concrete beam

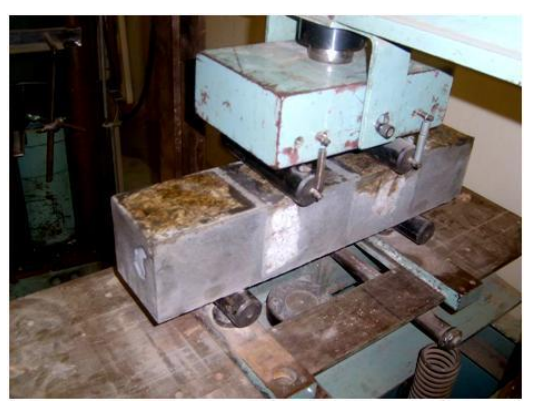

Figure 9. Flextural strength of concrete beam under considerations of load (unit flextural $\mathrm{MPa}=\mathrm{N} / \mathrm{mm}^{2}$ )

$$
\mathrm{Fb}=\mathrm{Pl} / \mathrm{bd}^{2}
$$

$\mathrm{P}=$ Maximum load $(\mathrm{KN})$;

$\mathrm{b}=$ Width of the specimen $(\mathrm{mm})$;

$1=$ supporting length $(\mathrm{mm})$;

$\mathrm{d}=$ Failure point depth $(\mathrm{mm})$.

\subsection{Water absorption test}

Lower permeability concrete is good quality and most important properties of concrete [22]. Lower permeability concrete is result from the entrance of water not absorbed the vulnerable to freezing and thawing. The test procedure involves drying DBA concrete block pavers specimens to a standard weight. The concrete block pavers are shown in Figure 10, are immersed in a water specified time period (28days). And take wet concrete specimens to put into weighing machines and analyses to the 2- stages for before and after 28 -days of the curing process. The average $\%$ of absorption of the examination sample is $5 \%$ rejection individual unit $\leq 7$ percentages.

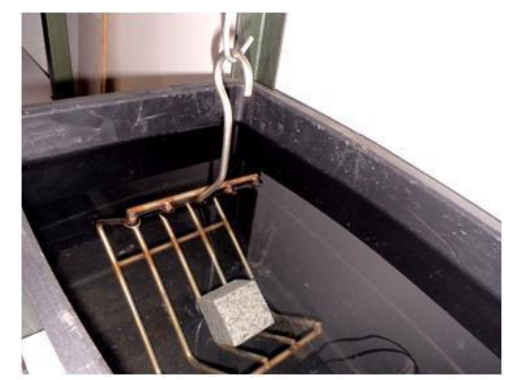

Figure 10. Samples immersed in a curing tub

\subsubsection{Permeability}

The permeability of concrete is the absorption of water at different levels and it depends upon the interrelated of pores. The permeability of concrete is not absorbed the directly in a water absorption it related the water-cement $(\mathrm{w} / \mathrm{c})$ ratio of concrete. Standard contents of water/cement ratios M25 concrete are $0.5 \%$, for example, 200 -litre water are required in $400 \mathrm{Kg}$ of cement content in the M25 concrete mix.

As shown in Figure 11, represents that the w/c ratios are the volume of water to the dependence upon the weight of cement quantities used in the required concrete mix. A lower $\mathrm{w} / \mathrm{c}$ ratio leads are high strength and occur some durability problems. If $\mathrm{w} / \mathrm{c}$ ratios are the great role of workability and strength portions of concrete. It proportionates added of quantity in conditions of zones and grades mix quantity. The blocks of concrete are convening the freezing and thawing necessities its need to be high quality s of concretes. The low permeability concretes are high-density solid matters. That requirements properties are available in high performance concretes mixes.

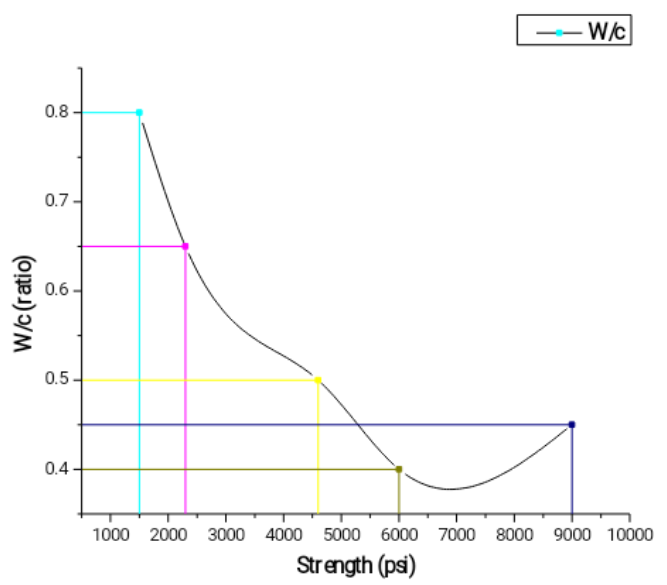

Figure 11. w/c ratios of direct effect of compressive strength of M25 grade concrete

\subsubsection{Absorption test result (28- days)}

The result of the absorption test of concrete blocks is shown in Table 5.

As shown in Figure 12, represents the absorption status for M25 concrete blocks it charts $\mathrm{Y}$-axis is percentage absorptions of water and ZY-axis represent the over the dry density of concrete blocks.

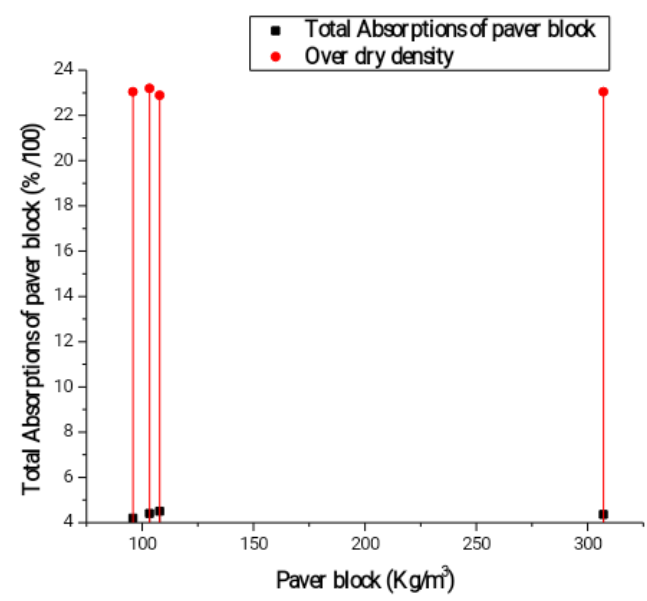

Figure 12. Absorption test results for M25 DBA \% of mix cement concrete paver blocks 
Table 5. Absorption test results for M25 DBA \% of mix cement concrete paver blocks

\begin{tabular}{ccccc}
\hline $\begin{array}{c}\text { Specimen } \\
\left(\mathbf{K g} / \mathbf{m}^{\mathbf{3}}\right)\end{array}$ & $\begin{array}{c}\text { Paver block } \\
\left(\mathbf{K g} / \mathbf{m}^{\mathbf{3}}\right)\end{array}$ & $\begin{array}{c}\text { Total Absorptions of paver block } \\
(\mathbf{\%} / \mathbf{1 0 0})\end{array}$ & $\begin{array}{c}\text { Moisture content } \\
\mathbf{( \% )}\end{array}$ & $\begin{array}{c}\text { Over dry density } \\
\left(\mathbf{K N} / \mathbf{m}^{\mathbf{3}}\right)\end{array}$ \\
\hline 1 & 95.87 & 4.2 & Neutral & 23.04 \\
2 & 103.31 & 4.4 & Neutral & 23.19 \\
3 & 107.923 & 4.5 & Neutral & 22.89 \\
Average & 307.103 & 4.36 & Neutral & 23.04 \\
\hline
\end{tabular}

\section{CONCLUSIONS}

This project aims to characteristics of experimental tests to conduct the dry bamboo ash composite mix in M25 grade concretes. Its exposed effect of tests is passes in required strength, a performance of concrete cube in a compression test, concrete cylinders in split tensile test and flexural strength of concrete beams. If 30 to $40 \%$ of DBA cement composite in more preferable and economic strength characters. It based on the experimental work results subsequent the concrete compression, flexural and split tensile test with DBA powder as \% mixed with replaced the materials of cement. The additions of the DBA inexpensive peak of view reduced the cement productions and save the natural assets. In additions of DBA, it improved the micron frictions bondings nature and corrosion resistance of RC bars. Sustainable replacement of the cement within DBA powder increased the strength of the concrete structure. If final analyses of experimental investigations characteristics investigations of dry bamboo ash partial replaced cement within M25 grade concrete is suitable for constructions and concrete structural frames.

\section{REFERENCES}

[1] Namango, S.S. (2006). Development of cost-effective earthen building material for housing wall construction. Investigations into The Properties of Compressed Earth Blocks Stabilized With Sisal Vegetable Fibres, Cassava Powder and Cement Compositions. Cassava Powder and Cement Compositions. A Doctoral Dissertation, Brandenburg Technical University, Cottbus, Germany.

[2] Fernández-Jiménez, A., Palomo, A. (2005). Composition and microstructure of alkali activated fly ash binder: Effect of the activator. Cement and Concrete Research, 35(10): 1984-1992. https://doi.org/10.1016/j.cemconres.2005.03.003

[3] Garmendia, L., San-José, J.T., García, D., Larrinaga, P. (2011). Rehabilitation of masonry arches with compatible advanced composite material. Construction and Building Materials, 25(12): 4374-4385. https://doi.org/10.1016/j.conbuildmat.2011.03.065

[4] Al-Homoud, M.S. (2005). Performance characteristics and practical applications of common building thermal insulation materials. Building and Environment, 40(3): 353-366. https://doi.org/10.1016/j.buildenv.2004.05.013

[5] Del Viso, J.R., Carmona, J.R., Ruiz, G. (2008). Shape and size effects on the compressive strength of highstrength concrete. Cement and Concrete Research, 38(3): 386-395.

https://doi.org/10.1016/j.cemconres.2007.09.020

[6] Van Chanh, N. (2004). Steel fiber reinforced concrete. In Faculty of Civil Engineering Ho chi minh City university of Technology. Seminar Material, pp. 108-
116.

[7] Muda, M.F.B. (2009). The Properties and Flexural Behaviour of Self Compacting Concrete Using Rice Husk Ash and Admixture. A Project Report (NOVEMBER 2009).

[8] Umoh, A.A., Odesola, I.A. (2015). Characteristics of bamboo leaf ash blended cement paste and mortar. Civil Engineering Dimension, 17(1): 22-28. https://doi.org/10.9744/ced.17.1.22-28

[9] Morsy, M.I.N. (2011). Properties of Rice Straw Cementitious Composite (Doctoral dissertation, Technische Universität).

[10] Choy, K.K., Barford, J.P., McKay, G. (2005). Production of activated carbon from bamboo scaffolding waste-process design, evaluation and sensitivity analysis. Chemical Engineering Journal, 109(1):

$147-165$ https://doi.org/10.29187/jscmt.2018.20

[11] Ahmaruzzaman, M. (2010). A review on the utilization of fly ash. Progress in Energy and Combustion Science, 36(3): $327-363$ https://doi.org/10.1016/j.pecs.2009.11.003

[12] Kowlessur, D., Topham, C.M., Thomas, E.W., O'Driscoll, M., Templeton, W., Brocklehurst, K. (1989). Identification of signalling and non-signalling binding contributions to enzyme reactivity. Alternative combinations of binding interactions provide for change in transition-state geometry in reactions of papain. Biochemical Journal, 258(3): 755-764. https://doi.org/10.1042/bj2580755

[13] Agarwal, S.K., Masood, I., Malhotra, S.K. (2000). Compatibility of superplasticizers with different cements. Construction and Building materials, 14(5): 253-259.

https://doi.org/10.1016/S09500618(00)00025-8

[14] Karol, R.H. (2003). Chemical Grouting and Soil Stabilization, Revised and Expanded. Engineering \& Technology, 3rd Edition. https://doi.org/10.1201/9780203911815

[15] Joseph, A.H., Webster, S.L. (1971). Techniques for Rapid Road Construction Using Membrance-Enveloped Soil Layers (No. Aewes-instruction-s-71-1). Army engineer waterways experiment station vicksburg ms. https://apps.dtic.mil/dtic/tr/fulltext/u2/720194.pdf, accessed on Jan. 16, 2020.

[16] Ene, E., Okagbue, C. (2009). Some basic geotechnical properties of expansive soil modified using pyroclastic dust. Engineering Geology, 107(1): 61-65. https://doi.org/10.1016/j.enggeo.2009.03.007

[17] Kumar, R., Kumar, M., Bansal, P.P. (2014). Effect of Partial Replacement of Cement by Fly Ash and Lime Sludge on Strength Characteristics of Concrete (Doctoral dissertation).

[18] Gambhir, M.L. (2013). Concrete technology: theory and practice. Tata McGraw-Hill Education. ISBN-10: 
9383286547, ISBN-13: 978-9383286546.

[19] Khatib, J.M. (2005). Properties of concrete incorporating fine recycled aggregate. Cement and Concrete Research, 35(4): 763-769. https://doi.org/10.1016/j.cemconres.2004.06.017

[20] Chia, K.S., Zhang, M.H. (2002). Water permeability and chloride penetrability of high-strength lightweight aggregate concrete. Cement and Concrete Research, 32(4): 639-645. https://doi.org/10.1016/S0008-
8846(01)00738-4

[21] McLeod, R.S. (2005). Ordinary Portland Cement. An Introduction to Nuclear Waste Immobilisation (Second Edition), 2014.

[22] Hofmann, D.C., Suh, J.Y., Wiest, A., Duan, G., Lind, M.L., Demetriou, M.D., Johnson, W.L. (2008). Designing metallic glass matrix composites with high toughness and tensile ductility. Nature, 451(7182): 1085. https://doi.org/10.1038/nature06598 